\title{
On the Diversity of Versions from the Perspective of Halliday's Systematic-Functional Grammar
}

\author{
Xiao-Ying YAN ${ }^{1, a}$ \\ ${ }^{1}$ Jincheng College of Sichuan University, Chengdu, Sichuan, China; School of Foreign Languages \\ of Sichuan Normal University, Chengdu, Sichuan, China \\ a1825428585@qq.com
}

Keywords: diversity, versions, Systematic-functional Grammar.

\begin{abstract}
Different translators have different versions of the same source text. This essay is to illuminate the reasons behind the phenomenon by using Halliday's Systematic-functional grammar. It is found that there are a series of factors which contribute to the diversity and the increase of the number of versions, namely the selection of words, of sentence patterns, of the structure of Theme and Rheme, the text structure, etc.
\end{abstract}

\section{Introduction}

We often discuss translation from the perspective of culture or function of translation, but the translation process itself is very important. A translator has to understand the source text by taking the textual context and its relevant cultural background for reference, selecting words and sentence patterns to formulate a text.Why do different translators produce different versions of the same source text during the translation process? As is known to us, a source text will have one-thousand versions if it is translated by one-thousand translators. Why? In the paper, diversity of versions will be illuminated from the perspective of systematic-functional grammar.

\section{Halliday's Systematic-Functional Grammar}

Since the 1960s, M.A.K. Halliday, the representative of the London School in linguistics, has established and developed systematic-functional grammar. Halliday always sees the language system as meaning potential and makes a long-term study on how the language system works. He holds that the language system should be systems inclusive of meaning potential and a process of selection. The speech generation process is also a process of selecting different sub-systems in the system network. When a specific linguistic form is selected, this is the realization of meaning potential in a system. When all the linguistic forms are picked in a linear sequence, it is the generation process of a sentence. Why does a speaker choose this word or phrase instead of others? It depends on the context of situation, namely the three factors of the context of situation. Halliday argues that field, tenor and mode are the three basic factors of context of situation. The language field refers to the social activity that contains in the discourse, and the style of a text is its most specific manifestation. Tenor is the collection of the roles of the participants and their relationship between them in an event. Mode means the choice of written or oral forms. To some extent, whether a particular linguistic form is chosen or not in a linear sequence lies in the field, tenor and mode of the context of situation in which it is generated. When all the positions in the linear sequence are filled with the words selected by a speaker, a sentence is produced, and it is the realization of meaning potential in syntactic level. Generally speaking, a text is composed of different sentences and how sentences are organized into a text is related to selection of theme and rheme and of the transition words by which different sentences are integrated with each other and the textual function can be realized which is one of 3 metafunctions of language. 


\section{Diversity of Versions}

In essence, translation is also a process of speech generation, which complies with the rules of speech production put forward by Halliday. The production of a translation text lies in the selection of linguistic forms in a linear sequence. A translation text consists of different sentences and a sentence is the basic unit of translation. When a translator translate a text, s/he will usually choose to translate it sentence by sentence except for some special locations of the text. Although translation is a process of speech generation, it has its own unique characteristics. Generally speaking, a translator has to generate a text strictly by following the meaning of its source text and there's no translation text which can be generated arbitrarily and the versions have to be common in meaning or at least in function with the source text. Otherwise it can not be called translation. And when a translator do his/her translation, the context of situation of the source text is accessible easily and unchangable. All the translators have to do their translation on the basis of the context of situation of the source text. And the translation text would better share the same context of situation. In terms of selection of linguistic forms, as translators we should consider what the social activity is mentioned in the source text, what the relationship between different people and what their roles or what entities are involved in and what their functions are, or what the relationship between people and entities is, what form the writer chooses, the oral or written, and the like. S/he has to take into account the three factors of context of situation. Under the same context of situation, all the versions can not be diverse arbitrarily. Therefore the diversity of versions means that it is the difference in form, not in meaning or function.

Why does a translator choose this form in the same position of a structure instead of that form? Why does a translator choose this word instead of that one? Why does a translator choose this sentence pattern instead of that one? Why does a translator pick this theme instead of that one? It depends on a certain probability which Halliday attributes to. As he said, some people prefer the word of "elevator" while others like the word of "lift" more. Actually, the probability connects with a translator's education background, personal experience, frequency of one particular linguistic form, etc. The probability of selection of linguistic forms results in the diversity of versions.

\section{Diversity Caused by Selection of Words}

Translation is a process of selecting particular linguistic forms in a linear sequence from left to right. In a translation practice, it may be inevitable for a translator to select a particular word from a group of words consciously or unconsciously. As we have discussed above, which word are chosen by a translator may get involved in the probability. That is, the selection of a particular word is subjunctive, which is relative to the translator's frequency of this word, personal experience, and many other personal factors. In the following text, one paragraph is picked to illustrate the diversity of versions from a text of the 29th Hansuyin Award for Young Translators.

ST. 在这一历史大潮中，中国现在比历史上任何时期都更接近中华民族的伟大复兴。正如 “一带一路” 被越来越多的国家认识到不是中国的独角戏, 而是沿途民族的大合唱, 每个中国 人对于客观与主观世界的深刻、自觉的理性开发，最终将汇集于前所未有的“中国梦”的实现。

Firstly, we just take the word of “复兴” as an example. Due to the differences between English and Chinese, there are not two words which are absolutely synonymous. In the translation process, a translator tends to consult a dictionary for some key words as s/he is not a native speaker in case that there is any mistake is made. And seemingly we can find several candidates for the word of “复兴”, namely revival, Renaissance, and rejuvenation. Firstly, "Renaissance” can be excluded because both its denotation and connotation are inconsistent with the phrase of “中华民族的伟大复兴”. From the entries of "revive" in a dictionary we can see: "revival” refers to the discovery from a disease, fainting, or other negative states. While "rejuvenation" refers to one's looking young and being full of vitality. In terms of mode, "rejuvenation" is more formal than "revival". In terms of field and tenor, we know from the dictionary that "rejuvenation" is more suitable than "revival". As translators, we can not neglect the context of situation of the source text and accually we can do our translation better according to the context of situation. However, once a translator can not identify the context of 
situation, there would be another choice in the same position of the sentence. This would add the numbers of translation versions, which would contribute to the diversity of versions which is not supported by anyone. A translator's correct identification of the context relies on whether s/he is proficient in English or not. In other words, it is relative to his/her education background.

E.g. 1. 在这一历史大潮中，中国现在比历史上任何时期都更接近中华民族的伟大复兴。

Version1. The rejuvenation of the Chinese nation is closer at the historical point than ever before.

Version2. In this great historical trend, China is now closer to the great rejuvenation of the Chinese nation than ever before.

Version3. In this tide of history, China is now closer to the great rejuvenation of the Chinese nation than at any other time of its history.

Version4. In the historical tide, China is close to the great rejuvenation of the Chinese nation than any other time.

E.g. 2. 正如“一带一路”被越来越多的国家认识到不是中国的独角戏，而是沿途民族的大合 唱, 每个中国人对于客观与主观世界的深刻、自觉的理性开发, 最终将汇集于前所未有的“中 国梦”的实现。

Version 1. As more and more countries realize that "the One Belt and One Road" is a chorus of nations along the road instead of China's one nation show.

Version 2. More and more people realize that “The Belt and Road Initiatives” is not China's monologue, but the people's chorus along the way.

Version 3. The belt and road, as more and more countries has realized, is not a monodrama, but a cantata of all peoples on the way.

As for the word of “独角戏” in Chinese language, different translators choose different words from a collection of synonyms such as one man's show, monodrama, monologue. And it is also true for the chinese word “大合唱”. Some may choose “Chorus” while others may pick “cantata” instead. It is the selection of words that depends on the probability of its use. In other words, a translator tends to select the word from the collection of synonyms which he is more familiar with and used more often. Different translators select different words from a group of synonyms because they has different Probability for the same word. In other words, in terms of the same word “大合唱”, “chorus” has higher use frequency for a translator, but "cantata” is higher for another translator. A conclusion can be made that probability of word selection results in the increase of the number of the versions.

\section{Diversity Caused by Sentence Patterns}

As for the word of “独角戏” in Chinese language, different translators choose different words from a collection of synonyms such as "one man's show”, “monodrama”, "monologue”. And it is also true for the Chinese word “大合唱”. Some may choose “ Chorus” while others may pick “cantata” instead. The selection of words that depends on the probability of its use. In other words, a translator tends to select a word from the collection of synonyms which he is more familiar with . In other words, in terms of the same word “大合唱”, “chorus” has higher use frequency for a translator , but “cantata” is higher for another translator. the difference of word selection results in the increase of the number of the versions, which contributes to the diversity of versions.

E.g.3. 正如“一带一路”被越来越多的国家认识到不是中国的独角戏, 而是沿途民族的大合 唱, 每个中国人对于客观与主观世界的深刻、自觉的理性开发, 最终将汇集于前所未有的“中 国梦”的实现。

Version 1. As more and more countries realize that "the One Belt and One Road" is a chorus of nations along the road instead of China's one nation show.

Version 2. More and more people realize that “The Belt and Road Initiatives” is not China's monologue, but the people's chorus along the way.

Version 3. The belt and road, as more and more countries has realized, is not a monodrama, but a cantata of all peoples on the way.

Version 4. The belt and road, is a cantata of all people on the way rather than China's monodrama. 
For the second sentence, some translator may choose "Not...but..." while some may choose “rather than" or “instead of”. The selection of the counterparts of “不是......而是......" also depends on the frequency of their use or personal preference. Different translators choose different sentence patterns, which also contributes to the increase of the number of versions.

\section{Diversity Caused by Selection of Text Structures}

As is mentioned above, there are three meta-functions, namely ideational function, interpersonal functions and discourse function. The text function among them is mainly realized by the structure of Theme \& Rheme, information structure and ways of cohesion. The Theme below is represented by a horizontal line + "T", and the boundary between the Theme and the rheme is marked by "//". Words for cohesion is contained in the mark of "()". Translation Text 1 is translated by one classmate of the same class, translation text 2 by the author, and translation Text 3 by Professor Yan Linhai.

E.g. 4: 在这一历史大潮中, 中国现在比历史上任何时期都更接近中华民族的伟大复兴。正 如“一带一路”被越来越多的国家认识到不是中国的独角戏, 而是沿途民族的大合唱, 每个中 国人对于客观与主观世界的深刻、自觉的理性开发, 最终将汇集于前所未有的“中国梦”的实 现。

Version 1. In the historical tide T//, China is close to the great rejuvenation of the Chinese nation thant any other time. More and more people realize T// that "The Belt and Road Initiatives" is not China's monologue, but the people's chorus along the way. The "Chinese Dream" T// will be unprecedentedly realized through people's deep and self-conscious rational development of the objective and subjective world.

Version 2. (As we know) T//, more and more people from different countries come to know that the Belt and Road Initiative (B\&R) is a chorus of many countries along the Silk Road instead of China's solo.The rejuvenation of the Chinese nation $\mathrm{T} / /$ is closer at the historical point than ever before. Each Chinese's deep, self-awakening and rational exploration towards both objective and subjective worlds T// will finally contribute to accomplishment of China Dream which will be unprecedented.

Version 3. In this great historical trend $\mathrm{T} / /$, China is now closer to the great rejuvenation of the Chinese nation than ever before. The belt and road $\mathrm{T} / /$, as more and more countries has realized, is not a monodrama, but a cantata of all people on the way. All Chinese people T//will bring their rational development into full play-the rational development of the objective and subjective worlds in the process of realizing their unprecedented "China Dream".

From the above three translations we can see that different translators adopt different Themes and Rhemes. And the author use "as we know" to connect the paragraphs, so that the translation is more natural and smooth, but it is an addition into the target language, which does not exist in the content. At the same time the translator made a certain adjustment of the word order, hoping that all the sentences are integrated in meaning. But translation text 3 did it better than another two versions.Here we take the sentence as an example: “一带一路”被越来越多的国家认识到不是中国的独角戏, 而 是沿途民族的大合唱”, which is translated as “The belt and road, as more and more countries has realized, is not a monodrama, but a cantata of all people on the way”. In the sentence, the structures of Theme \&Rheme and information are consistent with each other. What is more important, the translator takes "The belt and road" as the Theme of the whole structure. It means "The belt and road Initiative" and its relevant contents are what the author of the source text want to emphasize and convey. Following the structure of source language, both the translators of translation text 1 and text 2 neglect what the author want to emphasize. Different selections of the structure of Theme and Rheme, information structure and transition words also contribute to the increase of the number of versions.

\section{Summary}

Conclusion can be made here that Halliday's systematic-functional grammar is conducive to illuminate the diversity of versions and there are many factors which can lead to the increase of the 
number of versions. They are the selection of words, the selection of sentence patterns, the selection of the Theme and Rheme, of transition words, and the like. All of them contributes to the diversity of versions and therefore the increasing of number of versions. And actually there are many other versions which are not made by human beings but application programs like google Translation online. Systematic-functional grammar to throw light on the generation process of natural languages. Of course the diversity of versions caused by application programs completely or partially may be elucidated from the perspective of Systematic-functional Grammar because almost all the translation softwares are based on corpus which is a collection of natural sentences itself.

\section{Acknowledgement}

This paper is sponsored by Sichuan Provincial Department of Education (Project No.: 13SB0192).

\section{References}

[1] Hu Zhuanglin \& Zhu Yongsheng \& Zhang Delu, et., The Introduction to System Functional Linguistics, Beijing, Peking University Press, 2008.

[2] Liu Runqing, Western Linguistic School, Shanghai, Foreign Language Teaching and Research Press, 2002.

[3] Wu Jianqing, Probability, Precision and Proximity of News Semantics, Chinese Foreign Languages. 63(2015) 42-49.

[4] M.A.K. Halliday, An Introduction to Functional Grammar, Beijing, Foreign Language Teaching and Research Press, 2008. 